\title{
Innovative Teaching Learning Methods for Health Professional Educators - Experiences Shared by Participants during an Online Learning Forum
}

\author{
Joseph, N.
}

\begin{abstract}
Background: There is a need to introduce self-styled innovative teaching learning ( $T L)$ methods to make class room or bed side teaching more interesting for medical graduates.

Methods: This research work show cases the experience shared by 26 FAIMER fellows who participated in a Mentor-Learner (ML) web discussion on self-styled innovative TL methods. Selfstyled TL methods conducted earlier either in large or small group setting were shared by the participants.

Results: Self-styled T-L methods in the large group settings involved group activities and usage of different teaching modalities. It improved the attention span of students. Self-styled T-L methods implemented in the small group settings improved group discussion. Students felt benefitted by learning from one another. These sessions helped in better retention of facts and the setting favoured easier clarification of doubts from the facilitators. Assessment methods were used more in small compared to large group settings. Challenges involved during preparatory stage and inability to bring about universal student participation during implementation stage of various suggested methods were experienced by most facilitators in both types of setting. Majority of the methods could not touch beyond the "Cognition" component of the Miller's Pyramid of Assessment.
\end{abstract}

Conclusion: Effective implementation of self-styled methods require good pre-planning and a wellsupported feedback/evaluation process during the post implementation phase. It is also recommended to introduce innovative TL methods which strengthens the "Behaviour" component of the Miller's Pyramid of Assessment at various teaching institutions.

Keywords: Self-styled innovative teaching learning methods, Mentor-Learner web discussion, Experience sharing

\section{Introduction}

Medical schools need to periodically update their teaching learning (TL) methodologies so as to ensure that classroom TL experience is an interesting experience for the students. In order to avoid the learning experiences in classrooms from becoming monotonous, there is a need to redefine it by introducing innovative TL methods.

This would further validate the principle of learning and reaffirm that students learn best

Dr. Nitin Joseph, Associate Professor, Member of Medical Education Unit, Department of Community Medicine, Kasturba Medical College, Light House Hill Road, Mangalore, Manipal Academy of Higher Education, Manipal, India.

Email:drnitinjoseph@gmail.com when they see, listen, and do an activity simultaneously.

There is a need to tap information on several such innovative TL methods implemented by academicians during their teaching experiences so as to replicate the same at various professional colleges.

Listserv based discussions serve an excellent platform for discussion on innovative TL methods and other important issues

concerning medical education among academicians placed in different parts of the world. This research work is the scholarly report of one such discussion on experience

DOI: http://doi.org/10.4038/seajme.v14i2.224 
sharing of self-styled TL methods by the participants.

\section{Methods}

These asynchronous online discussions took place using the listserv hosted by PSG FAIMER Regional Institute, Coimbatore, India. It was held in 2015 during the last week of December. The participants were of a varied back ground i.e. from Medical, Dental, Nursing and Physiotherapy sciences based in India and abroad. They were invited to share their experiences, perceived benefits and challenges, regarding any self-styled innovative TL methods implemented by them, in large or small group setting in the past. Participants were given the opportunity to share from others' (colleagues/ friends) experiences too.

Identification of the immediate learning needs of learners just prior to the start of the discussion was done using survey monkey. Even questions on perceived barriers in relation to the topic of discussion was part of the survey. This was found to benefit participants in a previous online discussion moderated by Dongre et al., (2010).

The moderators had a separate channel of communication using WhatsApp.

The key challenge in ML web discussion was to maintain an optimum level of online participation. Therefore to encourage active participation in this web discussion, the moderators sent frequent reminders through phones and emails to the non-participants.

To maintain the enthusiasm of the participants and to encourage their contribution throughout, a case scenario with fictitious names were framed in the present web discussion, as also done by Ladhani et al., (2011) in a previous online discussion.

\section{Results}

A total of 26 participants took part and a total of 103 mails related to the topic of discussion were posted in the listserv during the week.

The various self-styled TL methods narrated by the participants is presented in Table 1.

Majority of the self-styled large group TL methods involved usage of multiple teaching modalities and multiple activities, with the aim of increasing attention span of the students.
The multiple teaching modalities which were used were videos, power point slides and flash cards. The multiple activities involved case based learning, open book evaluation, framing of problem based reasoning type of short answer questions and solving of picture based case scenario stems by the students. However, a common challenge faced by the facilitators, in spite of using multiple activities in sequence during large group teaching was, inability to involve all the participants. Moreover ensuring availability of teaching aids like video lectures for all the topics and of flash cards for all the students, required good amount of preparation during the preimplementation stage. Assessment methods were observed to be minimal in large group setting. Another important drawback of these large group TL methods were that it could not touch beyond the "Knows" and "Knows how" level of the Miller's Pyramid of Assessment.

Majority of the self-styled TL methods in small group setting were directed towards integrated teaching of basic sciences with clinical and applied sciences. Factors which favoured learning process in this setting was learning from one another, better clarification of doubts from the facilitators and better retention of concepts. Few of these small group TL methods touched the "Shows how" level of Miller's Pyramid of Assessment. This included "Triangular model" to teach Anatomy and "Role play in Orthopaedics". Only two models namely, "Integrated teaching with early patient encounters" and its reverse model touched the "Does" level of Miller's Pyramid of Assessment by involving real patient for teaching medical undergraduates. Challenges identified with respect to prior preparations in small group setting were, in areas such as, faculty coordination, patient availability, drafting of case scenarios and framing suitable questions. Moreover in small group teaching, requirement of prior preparation by the participants for the exercise, played a crucial role in the success of the model.

For active participation of silent students and for further improvisation of any newly implemented T-L method, taking feedback from students soon after the session was suggested by few fellows. This along with private conversation and counselling were the other suggested remedies for helping demotivated students. 
Table 1: Self-styled teaching learning (TL) methods implemented by participants in large and small group settings

Large group setting

\begin{tabular}{|c|c|c|c|c|c|c|c|}
\hline $\begin{array}{l}\text { Name of TL } \\
\text { method } \\
\text { suggested } \\
\text { by the } \\
\text { participant }\end{array}$ & $\begin{array}{l}\text { Type of } \\
\text { activity/ } \\
\text { Setting/ } \\
\text { Learning } \\
\text { domains }\end{array}$ & $\begin{array}{c}\text { Target } \\
\text { audience/ } \\
\text { Group } \\
\text { characteristic/ } \\
\text { Time allotted }\end{array}$ & Methodology & $\begin{array}{c}\text { Evaluation } \\
\text { process }\end{array}$ & $\begin{array}{l}\text { Perceived } \\
\text { benefits of } \\
\text { the method }\end{array}$ & $\begin{array}{l}\text { Perceived } \\
\text { challenges in } \\
\text { the method }\end{array}$ & $\begin{array}{l}\text { Remedial } \\
\text { measures } \\
\text { suggested } \\
\text { during the } \\
\text { discussion }\end{array}$ \\
\hline
\end{tabular}

Hybrid

tutorial
Tutorials, Cognitive and Affective
125 MBBS

students, 1

tutor, 1 hour
Row wise division of tutorial subtopics, students to write answers in note book, discuss answer with their neighbours, read book to find the right answer, a randomly chosen student from each row to take part in a $\mathrm{CBL}$ session. $\mathrm{CBL}$ question was projected on a power point slide for the benefit of the audience. One randomly chosen CBL participant to present solution to the entire class.

Inputs on missed points by audience and faculty towards the end.
Students

actively

involved

throughout.

Improved

their attention

span.

Nil

Usage of

several

innovative TL

methods

made the

class

interesting.
No

discussion, only

Noise

generated

during paired discussions. exchange of note books for correcting one another's answers.

\begin{tabular}{|c|c|c|c|c|c|c|c|}
\hline Flash cards & $\begin{array}{l}\text { Theory class, } \\
\text { Cognitive }\end{array}$ & $\begin{array}{l}200 \text { MBBS } \\
\text { students or } 75 \\
\text { Paediatric Post } \\
\text { graduates, } 1 \\
\text { tutor, } 1 \text { hour }\end{array}$ & $\begin{array}{l}\text { Students have to } \\
\text { display card } \\
\text { depicting clarity } \\
\text { with the topic } \\
\text { taught when asked } \\
\text { by the faculty, at } \\
\text { any point in the } \\
\text { class - fully clear } \\
\text { (green card), } \\
\text { somewhat clear } \\
\text { (yellow card), not } \\
\text { clear (red card) }\end{array}$ & $\begin{array}{l}\text { Card based } \\
\text { quiz at the } \\
\text { end - "yes" } \\
\text { to an } \\
\text { answer } \\
\text { (green } \\
\text { card), "not } \\
\text { sure" to an } \\
\text { answer } \\
\text { (yellow } \\
\text { card), "no" } \\
\text { to an } \\
\text { answer (red } \\
\text { card) }\end{array}$ & $\begin{array}{l}\text { Low cost } \\
\text { technology } \\
\text { Gives periodic } \\
\text { check of } \\
\text { students' } \\
\text { understanding } \\
\text { of the lecture. }\end{array}$ & $\begin{array}{l}\text { Coloured } \\
\text { cards were } \\
\text { laborious to } \\
\text { prepare and } \\
\text { distribute to } \\
\text { all. } \\
\text { Few } \\
\text { responses } \\
\text { might have } \\
\text { been triggered } \\
\text { seeing others' } \\
\text { responses. }\end{array}$ & $\begin{array}{l}\text { Use of } \\
\text { clickers } \\
\text { instead of } \\
\text { flash cards. }\end{array}$ \\
\hline $\begin{array}{l}\text { Not } \\
\text { suggested }\end{array}$ & $\begin{array}{l}\text { Tutorials, } \\
\text { Cognitive }\end{array}$ & $\begin{array}{l}150 \text { MBBS } \\
\text { students, } 1 \\
\text { tutor, } 1 \text { hour }\end{array}$ & $\begin{array}{l}\text { Video lecture } \\
\text { followed by didactic } \\
\text { lecture on the same } \\
\text { topic the very next } \\
\text { day for } 75 \text { students } \\
\text { of study group. }\end{array}$ & $\begin{array}{l}\text { Class test } \\
\text { conducted } \\
\text { for both } \\
\text { study group } \\
\text { and control } \\
\text { group. }\end{array}$ & $\begin{array}{l}\text { Performance } \\
\text { in class test } \\
\text { was } \\
\text { significantly } \\
\text { better in the } \\
\text { study group. }\end{array}$ & $\begin{array}{l}\text { Video lectures } \\
\text { were not } \\
\text { available for } \\
\text { all the theory } \\
\text { topics. }\end{array}$ & Nil \\
\hline
\end{tabular}




\begin{tabular}{|c|c|c|c|c|c|c|c|}
\hline & & & $\begin{array}{l}\text { Only didactic } \\
\text { lecture and no } \\
\text { video lecture for } 75 \\
\text { students of control } \\
\text { group. }\end{array}$ & $\begin{array}{l}\text { Process } \\
\text { evaluation } \\
\text { feedback } \\
\text { taken in } \\
\text { study group. }\end{array}$ & $\begin{array}{l}\text { Positive } \\
\text { feedback of } \\
\text { the process } \\
\text { was given by } \\
\text { the students. } \\
\text { Doubts in } \\
\text { video lecture } \\
\text { could be } \\
\text { clarified } \\
\text { during } \\
\text { didactic } \\
\text { lecture. }\end{array}$ & & \\
\hline $\begin{array}{l}\text { Not } \\
\text { suggested }\end{array}$ & $\begin{array}{l}\text { Tutorials, } \\
\text { Cognitive and } \\
\text { Affective }\end{array}$ & $\begin{array}{l}60 \text { MBBS } \\
\text { students } \\
\text { divided into } \\
\text { groups of } 5 \\
\text { each, } 1 \text { tutor, } 1 \\
\text { hour }\end{array}$ & $\begin{array}{l}\text { Framing of problem } \\
\text { based reasoning } \\
\text { type of short } \\
\text { answer questions } \\
\text { by groups by } \\
\text { referring to the text } \\
\text { book. Followed by } \\
\text { inter group } \\
\text { questioning and } \\
\text { answering session. }\end{array}$ & Nil & $\begin{array}{l}\text { Students } \\
\text { were involved } \\
\text { throughout } \\
\text { the class. } \\
\text { Healthy inter } \\
\text { group } \\
\text { competition to } \\
\text { foster each } \\
\text { other's } \\
\text { learning. }\end{array}$ & $\begin{array}{l}\text { Few students } \\
\text { were silent } \\
\text { spectators to } \\
\text { the } \\
\text { proceedings. } \\
\text { Time } \\
\text { constraints. }\end{array}$ & $\begin{array}{l}\text { Facilitators } \\
\text { in between } \\
\text { need to ask } \\
\text { questions to } \\
\text { the } \\
\text { students. } \\
\text { This would } \\
\text { encourage } \\
\text { participation } \\
\text { from silent } \\
\text { students. }\end{array}$ \\
\hline $\begin{array}{l}\text { Not } \\
\text { suggested }\end{array}$ & $\begin{array}{l}\text { Theory class, } \\
\text { Cognitive and } \\
\text { Affective }\end{array}$ & $\begin{array}{l}90 \text { BDS } \\
\text { students, } 1 \\
\text { tutor, } 1 \text { hour } \\
\text { Students } \\
\text { divided into } 10 \\
\text { sub-groups }\end{array}$ & $\begin{array}{l}\text { Topic given } 1 \text { week } \\
\text { before for } \\
\text { preparation. } \\
\text { Session starts with } \\
\text { tutor asking a } \\
\text { question related to } \\
\text { the topic and a } \\
\text { randomly chosen } \\
\text { member from every } \\
\text { sub-group to } \\
\text { contribute one } \\
\text { answer to be } \\
\text { written on the } \\
\text { board. Pauses } \\
\text { introduced to give } \\
\text { students time to } \\
\text { recollect and say } \\
\text { answers } \\
\text { The entire cycle } \\
\text { repeats over } 20 \\
\text { minutes with more } \\
\text { questions. } \\
\text { Each sub-group to } \\
\text { prepare a two slide } \\
\text { quick power point } \\
\text { presentation to } \\
\text { summarise the } \\
\text { discussions. (15 } \\
\text { minutes) } \\
\text { Any member of a } \\
\text { randomly chosen } \\
\text { sub-group to make } \\
\text { the presentation to }\end{array}$ & $\begin{array}{l}\text { Every } \\
\text { participant } \\
\text { towards the } \\
\text { end has to } \\
\text { answer to a } \\
\text { case } \\
\text { scenario } \\
\text { related to } \\
\text { the topic } \\
\text { discussed. }\end{array}$ & $\begin{array}{l}\text { Group activity } \\
\text { kept students } \\
\text { busy } \\
\text { throughout. } \\
\text { Multiple } \\
\text { modalities } \\
\text { helped to } \\
\text { stimulate } \\
\text { learning } \\
\text { process } \\
\text { among them. } \\
\text { Better } \\
\text { retention of } \\
\text { information } \\
\text { was } \\
\text { observed. }\end{array}$ & $\begin{array}{l}\text { There were } \\
\text { few students } \\
\text { who did not } \\
\text { actively } \\
\text { participate. }\end{array}$ & $\begin{array}{l}\text { Obtaining } \\
\text { feedback } \\
\text { from all } \\
\text { participants } \\
\text { might help } \\
\text { to identify } \\
\text { possible } \\
\text { reasons for } \\
\text { minimal } \\
\text { participation } \\
\text { among few } \\
\text { students. }\end{array}$ \\
\hline
\end{tabular}


the entire class. (5

minutes)

Finally pictures with

case scenario

stems were given

to each of the

students to answer

independently

without any

discussion. (20

minutes)
Open book

self-

evaluation of Cognitive

answer

scripts
MBBS

students,

1 hour

Open book
self-
evaluation of
answer
scripts by
the students
after the
exam.

Written

examination
Students

were

instructed to

add

comments

regarding

missed

points

against each

answer.
Cannot be

repeated

every time as

the

seriousness of

the

examination

procedure will

be lost.

Nil

Marks

obtained in the

examination

cannot be

used for

assessment

purposes.

\section{Small group setting}

\begin{tabular}{|c|c|c|c|c|c|c|c|}
\hline $\begin{array}{l}\text { Triangular } \\
\text { model }\end{array}$ & $\begin{array}{l}\text { Dissection } \\
\text { hall, } \\
\text { Cognitive and } \\
\text { Psychomotor }\end{array}$ & $\begin{array}{l}20 \text { MBBS } \\
\text { students, } 1 \\
\text { tutor, } 2 \text { hours }\end{array}$ & $\begin{array}{l}\text { Didactic lecture by } \\
\text { tutor using a writing } \\
\text { board fitted against } \\
\text { the dissection } \\
\text { table, followed by } \\
\text { display of power } \\
\text { point slides using } \\
\text { the laptop on case } \\
\text { scenarios related to } \\
\text { applied Anatomy } \\
\text { and demonstration } \\
\text { of the relevant } \\
\text { Anatomy in the } \\
\text { cadaver/specimen } \\
\text { by the tutor. }\end{array}$ & $\begin{array}{l}\text { More case } \\
\text { based } \\
\text { exercises in } \\
\text { applied } \\
\text { Anatomy } \\
\text { were solved } \\
\text { by the } \\
\text { students at } \\
\text { the end. }\end{array}$ & $\begin{array}{l}\text { Training } \\
\text { based on } \\
\text { CBME } \\
\text { guidelines. } \\
\text { More attention } \\
\text { for slow } \\
\text { learners. } \\
\text { Easier for } \\
\text { students to } \\
\text { interact and } \\
\text { clarify doubts. }\end{array}$ & $\begin{array}{l}\text { Some faculty } \\
\text { members did } \\
\text { not cooperate } \\
\text { for the } \\
\text { implementation } \\
\text { of this model. }\end{array}$ & Nil \\
\hline $\begin{array}{l}\text { Role play in } \\
\text { Orthopaedics }\end{array}$ & $\begin{array}{l}\text { Clinical } \\
\text { postings in } \\
\text { Orthopaedics, } \\
\text { Cognitive and } \\
\text { Psychomotor }\end{array}$ & $\begin{array}{l}20 \text { MBBS } \\
\text { students, } 1 \\
\text { tutor, } 30 \\
\text { minutes }\end{array}$ & $\begin{array}{l}\text { Students grouped } \\
\text { themselves into } \\
\text { pairs to palpate } \\
\text { bony land marks } \\
\text { and to elicit joint } \\
\text { movements of one } \\
\text { another. }\end{array}$ & Nil & $\begin{array}{l}\text { Good } \\
\text { understanding } \\
\text { of the bony } \\
\text { land marks } \\
\text { and joint } \\
\text { movements in } \\
\text { relation to } \\
\text { human } \\
\text { Anatomy. }\end{array}$ & $\begin{array}{l}\text { Anatomical } \\
\text { knowledge of } \\
\text { most students } \\
\text { was } \\
\text { inadequate. } \\
\text { Female } \\
\text { students in this } \\
\text { role play had } \\
\text { issues } \\
\text { concerning } \\
\text { privacy. }\end{array}$ & $\begin{array}{l}\text { Prior } \\
\text { reading of } \\
\text { relevant } \\
\text { Anatomy. }\end{array}$ \\
\hline
\end{tabular}




\begin{tabular}{|c|c|c|c|c|c|c|c|}
\hline $\begin{array}{l}\text { Round table } \\
\text { brainstorming } \\
\text { technique }\end{array}$ & $\begin{array}{l}\text { Tutorials, } \\
\text { Cognitive }\end{array}$ & $\begin{array}{l}9 \text { MSc Nursing } \\
\text { PG students, } 1 \\
\text { tutor, } 30 \\
\text { minutes }\end{array}$ & $\begin{array}{l}\text { Students seated in } \\
\text { a circular manner. } \\
\text { The tutor starts by } \\
\text { asking a question. } \\
\text { Students are then } \\
\text { given } 5 \text { minutes } \\
\text { time to prepare the } \\
\text { answers. A paper } \\
\text { sheet is then } \\
\text { circulated. Each } \\
\text { student to say } \\
\text { aloud one answer } \\
\text { before writing the } \\
\text { same in the sheet. } \\
\text { The sheet is then } \\
\text { passed on to the } \\
\text { adjacent student till } \\
\text { all get a chance. }\end{array}$ & Nil & $\begin{array}{l}\text { All possible } \\
\text { answers to a } \\
\text { question were } \\
\text { discussed. } \\
\text { Balanced } \\
\text { student } \\
\text { participation } \\
\text { and } \\
\text { stimulation for } \\
\text { learning } \\
\text { among the } \\
\text { slow learners } \\
\text { were ensured. }\end{array}$ & $\begin{array}{l}\text { Selection of a } \\
\text { suitable } \\
\text { question with } \\
\text { multiple } \\
\text { answers is } \\
\text { required. } \\
\text { Few } \\
\text { misleading } \\
\text { discussions } \\
\text { took place } \\
\text { during the } \\
\text { session. }\end{array}$ & Nil \\
\hline $\begin{array}{l}\text { Not } \\
\text { suggested }\end{array}$ & $\begin{array}{l}\text { Tutorials, } \\
\text { Cognitive and } \\
\text { Affective }\end{array}$ & $\begin{array}{l}20 \text { MBBS } \\
\text { students, } 1 \\
\text { tutor, } 2.5 \text { hours } \\
\text { in classroom } \\
\text { setting }\end{array}$ & $\begin{array}{l}\text { Didactic lecture by } \\
\text { the tutor for } 1 \text { hour } \\
\text { followed by } \\
\text { distribution of } 6 \\
\text { public health } \\
\text { scenarios. Later } 3 \\
\text { days' time given for } \\
\text { literature search } \\
\text { and to prepare } \\
\text { research question } \\
\text { in PICO format. } \\
\text { Then brainstorming } \\
\text { session on the } \\
\text { searched resources } \\
\text { for } 30 \text { minutes } \\
\text { followed by } \\
\text { presentation } \\
\text { session of evidence } \\
\text { pertaining to each } \\
\text { public health } \\
\text { scenario using AV } \\
\text { aids for } 1 \text { hour. }\end{array}$ & $\begin{array}{l}\text { Students' } \\
\text { attitude, } \\
\text { group work } \\
\text { and } \\
\text { presentation } \\
\text { skills were } \\
\text { assessed. }\end{array}$ & $\begin{array}{l}\text { Best solution } \\
\text { or evidence } \\
\text { available } \\
\text { currently for } \\
\text { each scenario } \\
\text { was identified } \\
\text { using this } \\
\text { model. }\end{array}$ & $\begin{array}{l}\text { Participation } \\
\text { was } \\
\text { inadequate } \\
\text { among few } \\
\text { students. } \\
\text { Repeat of } \\
\text { scenarios } \\
\text { given to the } \\
\text { previous batch } \\
\text { led to copy of } \\
\text { the answers in } \\
\text { the } \\
\text { subsequent } \\
\text { batches. }\end{array}$ & $\begin{array}{l}\text { Framing } \\
\text { different } \\
\text { scenarios } \\
\text { for every } \\
\text { new batch. }\end{array}$ \\
\hline $\begin{array}{l}\text { Integrated } \\
\text { teaching with } \\
\text { early patient } \\
\text { encounters }\end{array}$ & $\begin{array}{l}\text { Tutorials, } \\
\text { Cognitive, } \\
\text { Affective and } \\
\text { Psychomotor }\end{array}$ & $\begin{array}{l}25 \text { MBBS } \\
\text { students, } 1 \\
\text { teacher from } \\
\text { each of the } 3 \\
\text { pre-clinical } \\
\text { subjects, } 1 \\
\text { clinician, } 3 \\
\text { hours }\end{array}$ & $\begin{array}{l}\text { Bed side case } \\
\text { study on a selected } \\
\text { disease in the } \\
\text { hospital. Visit to } \\
\text { laboratory to show } \\
\text { biochemical } \\
\text { procedures. The } \\
\text { disease topic } \\
\text { divided into three } \\
\text { subtopics related to } \\
\text { the basic science } \\
\text { subjects. Entire } \\
\text { student group to } \\
\text { prepare power } \\
\text { point slides for the } \\
\text { three sub topics } \\
\text { under the guidance } \\
\text { of the respective } \\
\text { basic science } \\
\text { faculties. }\end{array}$ & Nil & $\begin{array}{l}\text { Patient } \\
\text { encounter at } \\
\text { the start gave } \\
\text { stimulus for } \\
\text { learning } \\
\text { further about } \\
\text { the topic. } \\
\text { Integrated } \\
\text { teaching } \\
\text { helped in } \\
\text { better } \\
\text { understanding } \\
\text { of the } \\
\text { concepts. } \\
\text { Doubts of } \\
\text { students were } \\
\text { better clarified } \\
\text { due to the } \\
\text { presence of }\end{array}$ & $\begin{array}{l}\text { Patient } \\
\text { encounter not } \\
\text { always } \\
\text { possible } \\
\text { because of } \\
\text { lack of hospital } \\
\text { admissions. } \\
\text { To establish } \\
\text { coordination } \\
\text { among the } 4 \\
\text { faculty } \\
\text { members from } \\
\text { different } \\
\text { departments } \\
\text { was difficult. }\end{array}$ & $\begin{array}{l}\text { Sessions to } \\
\text { be timed } \\
\text { based on } \\
\text { patient } \\
\text { availability. }\end{array}$ \\
\hline
\end{tabular}




\begin{tabular}{|c|c|c|c|c|c|c|c|}
\hline & & & $\begin{array}{l}\text { Power point } \\
\text { presentation by any } \\
\text { randomly chosen } \\
\text { student to the } \\
\text { entire class and to } \\
\text { all the } 4 \text { faculty } \\
\text { members followed } \\
\text { by a discussion } \\
\text { towards the end. }\end{array}$ & & $\begin{array}{l}\text { multiple } \\
\text { subject } \\
\text { experts in a } \\
\text { single setting. } \\
\text { Students were } \\
\text { busy and } \\
\text { involved } \\
\text { throughout. }\end{array}$ & & \\
\hline $\begin{array}{l}\text { Not } \\
\text { suggested }\end{array}$ & $\begin{array}{l}\text { Tutorials, } \\
\text { Cognitive, } \\
\text { Affective and } \\
\text { Psychomotor }\end{array}$ & $\begin{array}{l}25 \text { MBBS } \\
\text { students, } 2 \\
\text { basic science } \\
\text { faculties, } 1 \\
\text { clinician, } 3 \\
\text { hours }\end{array}$ & $\begin{array}{l}\text { Didactic lectures } 30 \\
\text { minutes in Anatomy } \\
\text { and } 30 \text { minutes in } \\
\text { Physiology, } \\
\text { followed by bed } \\
\text { side teaching in the } \\
\text { hospital for } 30 \\
\text { minutes. }\end{array}$ & $\begin{array}{l}\text { MCQs, } \\
\text { SAQs, } \\
\text { OSCE for a } \\
\text { total of } 1 \\
\text { hour. } \\
\text { Feedback of } \\
\text { learning } \\
\text { experience } \\
\text { over } 30 \\
\text { minutes. }\end{array}$ & $\begin{array}{l}\text { Active } \\
\text { participation in } \\
\text { learning } \\
\text { throughout. } \\
\text { Retention of } \\
\text { basic science } \\
\text { concepts was } \\
\text { better. } \\
\text { This } \\
\text { integrated } \\
\text { teaching } \\
\text { model } \\
\text { ensured better } \\
\text { clarity of the } \\
\text { topic among } \\
\text { the students. }\end{array}$ & $\begin{array}{l}\text { Time } \\
\text { constraints. } \\
\text { Patient } \\
\text { availability. }\end{array}$ & $\begin{array}{l}\text { When } \\
\text { patients' } \\
\text { with the } \\
\text { concerned } \\
\text { morbidity } \\
\text { are } \\
\text { unavailable } \\
\text { in the } \\
\text { hospitals, } \\
\text { video } \\
\text { recording of } \\
\text { patient } \\
\text { consultant } \\
\text { interaction } \\
\text { could be a } \\
\text { useful } \\
\text { alternative. }\end{array}$ \\
\hline $\begin{array}{l}\text { Not } \\
\text { suggested }\end{array}$ & $\begin{array}{l}\text { Clinical } \\
\text { postings, } \\
\text { Affective and } \\
\text { Psychomotor }\end{array}$ & $\begin{array}{l}\text { Physiotherapy } \\
\text { under graduate } \\
\text { students, } \\
\text { Physical } \\
\text { medicine } \\
\text { residents }\end{array}$ & $\begin{array}{l}\text { During their first } \\
\text { week of training } \\
\text { they were } \\
\text { instructed to use } \\
\text { mobility aids for } \\
\text { locomotion. }\end{array}$ & Nil & $\begin{array}{l}\text { Beautiful } \\
\text { strategy to } \\
\text { teach } \\
\text { empathy. } \\
\text { Helped them } \\
\text { in career } \\
\text { building } \\
\text { process. }\end{array}$ & Nil & Nil \\
\hline
\end{tabular}

\section{Discussion}

The collective and collaborative learning opportunities offered through this discussion might have helped the participating fellows in framing newer innovative TL methods at their respective institutes. However it was observed that only few methods could go beyond the "Cognition" component of the Miller's Pyramid of Assessment. To touch the "Behaviour" component under Miller's Pyramid of Assessment, it is necessary to introduce TL methods at teaching institutions which strengthens the "Shows How" and "Does" levels.

Competency based medical education (CBME) in the recently revised medical curriculum by the Medical Council of India (2017) supports the need to introduce more such innovative TL methods in medical education.

\section{Conclusion}

The various self-styled TL methods implemented by the participants addressed several short comings in the current medical education system. However, effective implementation of self-styled methods require good pre-planning and a well-supported feedback/evaluation process during the post implementation phase. It is also recommended to introduce innovative TL methods which strengthen the "Shows How" and "Does" levels under "Behaviour" component of the Miller's Pyramid of Assessment at various teaching institutions.

\section{Acknowledgements}

I thank all the faculty members and alumni mentors of December 2015 ML web discussion session for their guidance. I thank the fellow co-moderators of first three weeks of discussion in the same month namely, Dr. 
Archana A. Dharwadkar, Dr. Anila Mathews, Dr. Girija Sivakumar and Dr. Rukmini MS and all the participants for their valuable guidance, active participation and continuous support throughout the preparatory and discussion phase. I also express my gratitude to Dr. Thomas V Chacko, Director, PSG FAIMER Regional Institute, Coimbatore, India for his constant support, guidance and encouragement throughout this fellowship programme.

\section{References}

Dongre, A.R., Chacko, T.V., Banu, S., Bhandary, S., Sahasrabudhe, R.A., Philip, S. \& Deshmukh, P.R. (2010). On-line capacity-building program on" analysis of data" for medical educators in the South Asia Region: a qualitative exploration of our experience. Education for Health, 23, 3, p. 425.
Ladhani, Z., Chhatwal, J., Vyas, R., Iqbal, M., Tan, C. \& Diserens, D. (2011). Online role-playing for faculty development. The Clinical Teacher, 8, 1, pp. 31-36.

Medical Council of India. (2017). 'Regulations on Graduate Medical Education, 1997. Amended upto July 2017'. Available at: https://www.mciindia.org/documents/rulesAndRe gulations/GME_REGULATIONS.pdf 